\title{
Perioperative Adjunct Magnesium Decreases Postoperative Opioid Requirements-A Meta-Analysis
}

\author{
Sudha Arumugam1, Christine S. M. Lau ${ }^{1,2}$, Ronald S. Chamberlain 1,2,3* \\ ${ }^{1}$ Department of Surgery, Saint Barnabas Medical Center, Livingston, USA \\ ${ }^{2}$ Saint George's University School of Medicine, True Blue, Grenada \\ ${ }^{3}$ Department of Surgery, New Jersey Medical School, Rutgers University, Newark, USA \\ Email: *rchamberlain@barnabashealth.org
}

Received 24 March 2016; accepted 23 May 2016; published 26 May 2016

Copyright (C) 2016 by authors and Scientific Research Publishing Inc. This work is licensed under the Creative Commons Attribution International License (CC BY). http://creativecommons.org/licenses/by/4.0/

(c) (i) Open Access

\section{Abstract}

Objectives: Magnesium (Mg) is the fourth most common cation in the body and has numerous physiological activities and anti-nociceptive effects. The anti-nociceptive effects are primarily mediated by regulation of calcium influx into the cell and antagonism of the $N$-Methyl-D-aspartate glutamate receptors. Opioids are widely used as analgesics to minimize postoperative pain, but their use is associated with various side effects as well as the potential for addiction and tolerance. Systemic Mg has been proposed as an adjunct to minimize postoperative pain in numerous clinical studies. This meta-analysis aims to critically examine the ability of perioperative intravenous (IV) Mg to reduce opioid use and its' side effects. Methods: A comprehensive literature search of Pub Med, Cochrane Central Registry of Controlled Trials, and Google Scholar (1966-2016) was performed to identify all randomized control trials (RCTs) assessing the use of perioperative IV Mg in the reduction of postoperative opioid consumption. Keywords searched included combinations of "magnesium", "pain", "postoperative", "preoperative", “analgesia" and "opioid". Inclusion criteria included RCTs comparing the use of perioperative IV Mg with a control group in adult patients ( $>18$ yrs) undergoing elective surgery. Cumulative opioid consumption within the first 24 hours (hrs) postoperative period and the incidence of nausea and vomiting were analyzed. Results: 14 RCTs involving 910 patients were identified (455 patients received Mg and 455 patients received placebo or no therapy). Opioid consumption was significantly decreased in the systemic Mg group (standard mean difference [SMD]: $1.39,95 \%$ CI 1.83 to $-0.96 ; p<0.001$ ) at 24 hrs postoperatively. Subgroup analysis revealed a significant reduction in the morphine consumption (SMD: $-1.37,95 \%$ CI: -1.79 to $-0.95 ; p<0.001$ ) with the use of IV Mg. There was a decrease in tramadol consumption; however, this did not reach statistical significance (SMD: $-1.74,95 \%$ CI: -4.62 to $1.13 ; p=0.234$ ). Systemic Mg adjunct had no significant effect on postoperative nausea and vomiting $(\mathrm{RR}=0.63 ; 95 \%$ ${ }^{*}$ Corresponding author.

How to cite this paper: Arumugam, S., Lau, C.S.M. and Chamberlain, R.S. (2016) Perioperative Adjunct Magnesium Decreases Postoperative Opioid Requirements-A Meta-Analysis. International Journal of Clinical Medicine, 7, 297-308. 
CI 0.38 to 1.04; $p=0.07$ ). Conclusion: Perioperative IV Mg administration reduces opioid use in the first 24 hours postoperatively without any serious adverse events. The decreased need for postoperative opioids in the Mg group was not associated with a decrease in opioid-related side effects such as nausea and vomiting. Mg is an efficacious adjunct for postoperative analgesia and should be considered in multimodal analgesic treatment plans. Additional studies are required to optimize the Mg dose and timing, and to address whether specific opioids display unique benefit or resistance to adjunct Mg therapy.

\section{Keywords}

Magnesium, Pain, Postoperative, Preoperative, Analgesia, Opioid

\section{Introduction}

Pain is an "unpleasant sensory and emotional experience associated with actual or potential tissue damage." [1]. Effective control and management of postoperative pain is not only a concern to the patient, but it is also important to the surgeon given the potential adverse effects of the physiologic response to both pain and its treatment following surgery. Inadequate postoperative pain management leads to worse outcomes in the immediate postoperative period which include not only patient discomfort but also increased risk of wound infection, and cardiovascular, respiratory and gastrointestinal complications [1]-[3]. Untreated acute pain leads to reduced patient satisfaction, increased morbidity and mortality, and higher costs of care [4]. Chronic post-surgical pain (CPSP) is an additional serious complication of major surgery and is defined as pain that develops after a surgical procedure, of at least 2 months duration, and is not the result of other causes or a pre-existing pain [5]. While most surgical patients heal within months and return to their baseline functional status, certain surgical procedures and surgical candidates are at increased risk of developing CPSP and using opioid medications in the long-term [6] [7]. Procedures associated with a high incidence of post-surgical pain include limb amputation (30\% - 50\%), breast cancer surgery $(20 \%-30 \%)$, thoracotomy $(30 \%-60 \%)$ and heart bypass surgery $(30 \%-50 \%)$ [8].

Opioid based analgesia plays a significant role in the control of postsurgical pain. Despite being very effective analgesics, opioids also have many undesirable side effects including sedation, respiratory depression, nausea and vomiting, hypotension and bradycardia, pruritus, and inhibition of bowel function. The treatment of complications such as nausea and pruritus commonly include the administration of antihistamines, which have an additive effect on sedation and respiratory depression. The incidence of respiratory depression, a major life threatening complication of opioids has been reported to be as high as 1 per 10,000 patients with patient controlled analgesia pumps [9] [10]. Given these complications, prolonged hospital stays, and higher hospital costs, the development of novel methods to reduce opioid use in the postoperative period is imperative [11].

The concept of multimodal analgesia for treating postoperative pain has become widely accepted and standard multimodal analgesic regimens tailored to specific surgical procedures have been adopted by many institutions [12]. The reliance on multiple medications and therapies inherent to the multimodal approach may even address individual patient differences in analgesic pharmacogenetics (allelic differences in single genes and the associated variability in specific medication responses). It was hypothesized that combining different drug classes with different mechanism of action within the central and peripheral nervous system would reduce opioid use, and decrease opioid related side effects [13] [14]. One such novel agent is intravenous magnesium.

Magnesium sulphate has been widely used as a tocolytic agent and an anticonvulsant for the treatment of preterm labour and pre-eclampsia, respectively [15] [16]. The magnesium ion was initially discovered to be an N-methyl-D-aspartate glutamate (NMDA) receptor blocker, which can alter the perception and duration of pain in animal studies [17]. Since then, magnesium (Mg) have been studied over many years as an adjunct to minimize postoperative pain. Adjunct Mg has been studied via several routes of administration (systemic, topical, intrathecal and epidural) however the systemic (intravenous route) is the most extensively studied [18].

Oliveira et al. conducted a meta-analysis involving 16 randomized control trials (RCTs) and 921 patients, and reported a significant decrease in opioid consumption by patients who received $\mathrm{Mg}(\mathrm{WMD})=-10.52 ; 95 \% \mathrm{CI}$, -13.5 .4 to $-7.54 \mathrm{mg}$ morphine IV equivalents, $p<0.001$ ) [19]. Subsequently, a significant number of additional 
RCTs have been published addressing perioperative IV Mg use with conflicting results. Kumar et al. (2013) studied IV Mg administration on postoperative opioid requirements in 60 patients undergoing infra-umbilical surgery (30 received IV Mg and 30 received normal saline)and reported a significant reduction inmorphine required in the first 24 hours in the Mg group (3.99+/- $1.25 \mathrm{mg}$ ) as compared to normal saline group $(7.13+/-2.68 \mathrm{mg})$ $(p<0.000)$ [20]. Conversely Frassanito et al. (2015) published a RCT involving 40 patients (20 patients received IV Mg and 20 patients received normal saline) undergoing total knee arthroplasty and reported no significant difference in the cumulative morphine consumption during the first 24 hours of the postoperative period [21].

Given the significant morbidity and myriad of complications associated with inadequate postoperative analgesia and the potential need of high dose opioid consumption this meta-analysis sought to critically examine the existing literature on the efficacy of perioperative IV Mg to reduce postoperative opioid consumption and identify any associated adverse events.

\section{Materials and Methods}

\subsection{Study Selection}

A comprehensive search of all published randomized control trials (RCTs) evaluating intravenous Mg to minimize postoperative pain was conducted using PubMed, Cochrane Central Registry of Controlled Trials, and Google Scholar (1966-2016). Additional citations were searched, using the references of the articles retrieved from prior publications. The last search was conducted on March 10, 2016 and only articles written in English were considered. Keywords searched included combinations of "magnesium”, "pain”, "postoperative pain”, and "opioid consumption". The following inclusion criteria were used: RCTs involving perioperative intravenous administration of Mg compared to an inactive (placebo or "no treatment") control group. In case of duplicate publications, only the most recent and updated report of the clinical trial was included. This study was conducted according to Preferred Reporting Items for Systematic Reviews and Meta-Analyses (PRISMA) guidelines.

\subsection{Data Extraction}

Articles retrieved from the searches were assessed for eligibility, and data pertaining to patients, intervention, control groups, outcomes, and methodology, were abstracted (Figure 1). Clinical outcomes of interest included cumulative opioid consumption within the first 24 hours postoperative period.

\subsection{Statistical Analysis}

For each trial, standard mean difference (SMD) with a 95\% confidence interval (95\% CI) for cumulative opioid consumption were calculated. An SMD of zero means that the new treatment and the placebo have equivalent effects. If improvement is associated with higher scores on the outcome measure, SMDs greater than zero indicate the degree to which treatment is more efficacious than placebo and SMDs less than zero indicate the degree to which treatment is less efficacious than placebo. Following are the guidelines for interpreting the magnitude of the SMD: small, SMD = 0.2; medium, SMD = 0.5; and large, SMD = 0.8 [22].

Meta-analysis of the pooled data was performed using the Comprehensive Meta-Analysis software Version 3 (Biostat, Englewood, NJ). In relative risk (RR) analysis, the studies reporting zero events in any group, a continuity correction factor of 0.5 was adopted to calculate the RR and variance. In the event of zero events in both groups, the RR was not calculable and the study was excluded from the meta-analysis. Both the fixed-effects model and random-effects model were considered, depending on the heterogeneity of the included studies. To assess the heterogeneity between studies, both Cochrane's Q statistic and $\mathrm{I}^{2}$ statistic was used. Heterogeneity was considered statistically significant when $p<0.05$ or $\mathrm{I}^{2}>50$. If heterogeneity was observed, data was analyzed using a random-effects model. Conversely, in the absence of heterogeneity, a fixed-effects model was assumed. The publication bias regarding the SMD of cumulative opioid consumption was first qualitatively evaluated by funnel plot, and further evaluated using Egger's and Begg's tests. A two-tailed $p$-value of $<0.05$ was considered statistically significant. Subgroup analysis was performed based on type of opioid that was usedmorphine and tramadol, type of surgery and time of administration (intraoperative + postoperative vs intraoperative alone). 


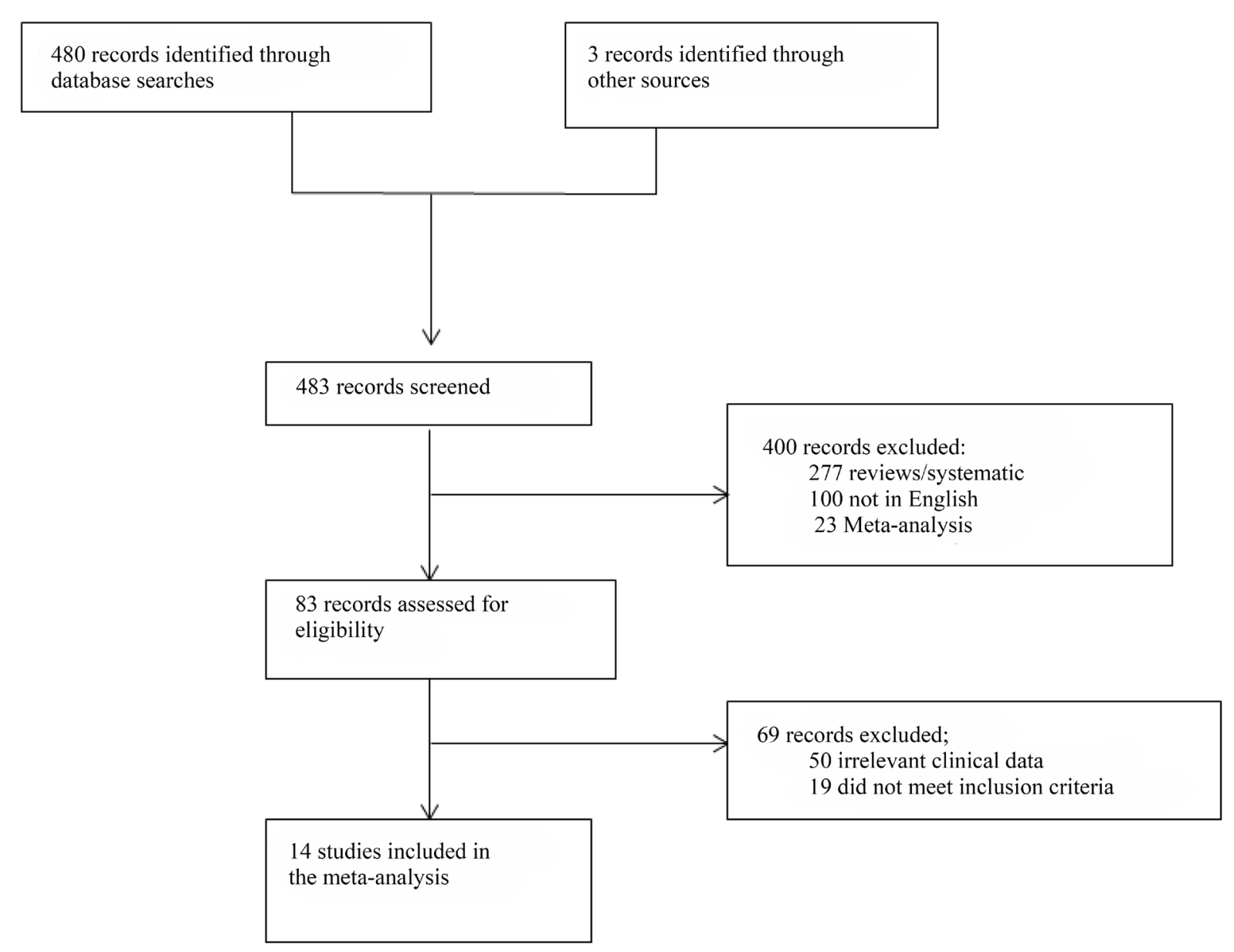

Figure 1. CONSORT diagram of the study selection process.

\section{Results}

\subsection{Demographic Characteristics of the Studies}

A total of 14 RCTs were identified, involving a total of 910 patients. 455 of these patients received Mg, and 455 patients received a placebo (Table 1 ).

\subsection{Effects of Magnesium on Opioid Consumption}

Data on opioid consumption in both the Mg group and the placebo group were reported in all 14 trials. There was significant heterogeneity between trials $\left(p<0.001, \mathrm{I}^{2}=84.41\right)$, and a random effects model was assumed. Meta-analysis showed a significant decrease in cumulative opioid consumption with the use of Mg compared to the control group (SMD: $-1.45,95 \%$ CI -1.86 to $-1.05 ; p<0.001$ and Mean difference (MD): $-8.90 \mathrm{mg}, 95 \%$ CI -11.18 to $-6.62 ; p<0.001$ ) (Figure 2). Individually, all studies reported a decrease in opioid consumption, of which 13 were statistically significant.

Subgroup analysis on the basis of type of opioids identified a significant reduction in the cumulative morphine consumption (SMD: $-1.37,95 \%$ CI -1.79 to $-0.95 ; p<0.001$ and MD: $-7.64 \mathrm{mg}$; $95 \%$ CI -9.53 to -5.75 ; $p<0.001$ ) with the use of $\mathrm{Mg}$. There was also a reduction in the cumulative tramadol consumption; however, results were not statistically significant (SMD: $-1.74,95 \% \mathrm{CI}-4.62$ to $1.13 ; p=0.234$ ) (Figure 3).

Subgroup analysis on the basis of type of operations identified a significant reduction in the cumulative morphine consumption with the use of Mg. (SMD of -0.89 in cholecystectomy, 0.65 in colorectal, -2.05 in coronary artery bypass, -1.17 in abdominal hysterectomy and -3.26 in prostatectomy surgeries). However the SMD was not statistically significant in thoracotomy, infra-umbilical and orthopedic surgeries (Figure 4). 
Table 1. Characteristics of all randomized controlled trials included in the current meta-analysis.

\begin{tabular}{|c|c|c|c|c|c|c|c|c|}
\hline $\begin{array}{l}\text { Author, } \\
\text { Year }\end{array}$ & Type of Surgery & $\begin{array}{l}\text { Method of Mg } \\
\text { administration }\end{array}$ & $\begin{array}{l}\text { Rate of } \\
\text { Mg } \\
\text { infusion }\end{array}$ & $\begin{array}{l}\text { Intraoperative } \\
\text { (I) or } \\
\text { Postoperative } \\
\text { (P) }\end{array}$ & $\begin{array}{c}\text { \# of Subjects } \\
\text { (\#Mg/\#Control) }\end{array}$ & Control & $\begin{array}{c}\text { Cumulative } \\
\text { |Morphine } \\
\text { Consumption } \\
\text { within first } 24 \\
\text { hours } \\
\text { (Magnesium } \\
\text { group) (mg) }\end{array}$ & $\begin{array}{l}\text { Cumulative } \\
\text { Morphine } \\
\text { Consumption with } \\
\text { first } 24 \text { hours } \\
\text { (Control group) } \\
\text { (mg) }\end{array}$ \\
\hline $\begin{array}{c}\text { Wilder- } \\
\text { Smith, } 1997 \\
{[35]}\end{array}$ & $\begin{array}{c}\text { Abdominal } \\
\text { hysterectomy }\end{array}$ & $\begin{array}{l}\text { Bolus + } \\
\text { continuous } \\
\text { infusion }\end{array}$ & $200 \mathrm{mg} / \mathrm{h}$ & I, P & $13 / 11$ & Placebo & $41.8 \pm 9.6$ & $46.8 \pm 14.1$ \\
\hline $\begin{array}{l}\text { Zarauza, } \\
2000[36]\end{array}$ & $\begin{array}{c}\text { Colorectal } \\
\text { surgery }\end{array}$ & $\begin{array}{l}\text { Bolus + } \\
\text { continuous } \\
\text { infusion }\end{array}$ & $\begin{array}{c}10 \\
\mathrm{mg} / \mathrm{kg} / \mathrm{h}\end{array}$ & I, P & $23 / 24$ & $\begin{array}{l}\text { Placebo } \\
\text { and } \\
\text { saline }\end{array}$ & $39.8 \pm 9.2$ & $46.6 \pm 11.3$ \\
\hline $\begin{array}{c}\text { Kara, } 2002 \\
\quad[37]\end{array}$ & $\begin{array}{c}\text { Abdominal } \\
\text { hysterectomy }\end{array}$ & $\begin{array}{l}\text { Bolus + } \\
\text { continuous } \\
\text { infusion }\end{array}$ & $500 \mathrm{mg} / \mathrm{h}$ & I, P & $12 / 12$ & Saline & $35.55 \pm 0.48$ & $43.43 \pm 7.2$ \\
\hline $\begin{array}{c}\text { Levaux, } 2003 \\
{[38]}\end{array}$ & $\begin{array}{l}\text { Orthopedic } \\
\text { surgery }\end{array}$ & $\begin{array}{l}\text { Continuous } \\
\text { infusion }\end{array}$ & $\begin{array}{l}50 \mathrm{mg} / \mathrm{kg} / \\
30 \mathrm{mins}\end{array}$ & I & $12 / 12$ & Saline & $42.37 \pm 17.75$ & $68.8 \pm 26.51$ \\
\hline $\begin{array}{c}\text { Bhatia, } 2004 \\
\text { [39] }\end{array}$ & $\begin{array}{c}\text { Open } \\
\text { cholecystectomy }\end{array}$ & $\begin{array}{c}\text { Bolus + } \\
\text { continuous } \\
\text { infusion }\end{array}$ & $\begin{array}{c}10 \\
\mathrm{mg} / \mathrm{kg} / \mathrm{h}\end{array}$ & I & $25 / 25$ & Saline & $13.7 \pm 3$ & $15.2 \pm 2.7$ \\
\hline $\begin{array}{l}\text { Seyhan, } 2006 \\
\text { (1) [40] }\end{array}$ & $\begin{array}{c}\text { Abdominal } \\
\text { hysterectomy }\end{array}$ & Bolus & $\begin{array}{c}40 \\
\mathrm{mg} / \mathrm{kg} / \mathrm{h}\end{array}$ & I, P & $20 / 20$ & Saline & $42.2 \pm 16.4$ & $64 \pm 10.2$ \\
\hline $\begin{array}{l}\text { Seyhan, } 2006 \\
\text { (2) }[40]\end{array}$ & $\begin{array}{c}\text { Abdominal } \\
\text { hysterectomy }\end{array}$ & $\begin{array}{l}\text { Bolus + } \\
\text { continuous } \\
\text { infusion }\end{array}$ & $\begin{array}{c}10 \\
\mathrm{mg} / \mathrm{kg} / \mathrm{h}\end{array}$ & I, P & $20 / 20$ & Saline & $39.2 \pm 15.5$ & $64 \pm 10.2$ \\
\hline $\begin{array}{l}\text { Seyhan, } 2006 \\
\text { (3) }[40]\end{array}$ & $\begin{array}{c}\text { Abdominal } \\
\text { hysterectomy }\end{array}$ & $\begin{array}{l}\text { Bolus + } \\
\text { continuous } \\
\text { infusion }\end{array}$ & $\begin{array}{c}20 \\
\mathrm{mg} / \mathrm{kg} / \mathrm{h}\end{array}$ & I, P & $20 / 20$ & Saline & $39.16 \pm 15.51$ & $64 \pm 10.2$ \\
\hline $\begin{array}{l}\text { Tauzin-fin, } \\
2006[41]\end{array}$ & Prostatectomy & $\begin{array}{l}\text { Continuous } \\
\text { infusion }\end{array}$ & $\begin{array}{c}16.7 \\
\mathrm{mg} / \mathrm{kg} / \mathrm{h}\end{array}$ & I & $15 / 15$ & Saline & $226 \pm 60$ & $444 \pm 73$ \\
\hline $\begin{array}{c}\text { Ozcan, } 2007 \\
{[42]}\end{array}$ & Thoracotomy & $\begin{array}{l}\text { Bolus + } \\
\text { continuous } \\
\text { infusion }\end{array}$ & $\begin{array}{c}10 \\
\mathrm{mg} / \mathrm{kg} / \mathrm{h}\end{array}$ & $\mathrm{P}$ & $12 / 12$ & Saline & $22.2 \pm 3.8$ & $23.5 \pm 4.6$ \\
\hline $\begin{array}{l}\text { O-mentes, } \\
2008[43]\end{array}$ & $\begin{array}{c}\text { Laparoscopic } \\
\text { cholecystectomy }\end{array}$ & $\begin{array}{l}\text { Continuous } \\
\text { infusion only }\end{array}$ & $\mathrm{n} / \mathrm{a}$ & I & $41 / 42$ & Saline & $12 \pm 6.4$ & $23 \pm 11.5$ \\
\hline $\begin{array}{l}\text { Ferasatkish, } \\
2008[44]\end{array}$ & $\begin{array}{l}\text { Coronary artery } \\
\text { bypass surgery }\end{array}$ & $\begin{array}{l}\text { Continuous } \\
\text { infusion only }\end{array}$ & $\begin{array}{c}32 \\
\mathrm{nmol} / \mathrm{kg} / \mathrm{h}\end{array}$ & I & $109 / 109$ & Saline & $13.6 \pm 2.8$ & $20.1 \pm 3.5$ \\
\hline $\begin{array}{l}\text { Oguzhan, } \\
2008[45]\end{array}$ & $\begin{array}{l}\text { Lumbar disc } \\
\text { surgery }\end{array}$ & $\begin{array}{l}\text { Continuous } \\
\text { infusion only }\end{array}$ & $\begin{array}{c}10 \\
\mathrm{mg} / \mathrm{kg} / \mathrm{h}\end{array}$ & I & $25 / 25$ & Saline & $56.27 \pm 18.16$ & $63.49 \pm 25.92$ \\
\hline $\begin{array}{c}\text { Kaya, } 2009 \\
{[46]}\end{array}$ & $\begin{array}{c}\text { Abdominal } \\
\text { hysterectomy }\end{array}$ & $\begin{array}{l}\text { Bolus + } \\
\text { continuous } \\
\text { infusion }\end{array}$ & $500 \mathrm{mg} / \mathrm{h}$ & I & $20 / 20$ & Saline & $30.2 \pm 10.2$ & $36.7 \pm 7.3$ \\
\hline $\begin{array}{l}\text { Dabbagh, } \\
2009[47]\end{array}$ & $\begin{array}{l}\text { Lower limb } \\
\text { surgery }\end{array}$ & $\begin{array}{l}\text { Continuous } \\
\text { infusion only }\end{array}$ & $8 \mathrm{mg} / \mathrm{kg} / \mathrm{h}$ & I & $30 / 30$ & Saline & $4.2 \pm 1.6$ & $9.8 \pm 1.2$ \\
\hline $\begin{array}{l}\text { Saadawy, } \\
2010[48]\end{array}$ & $\begin{array}{c}\text { Laparoscopic } \\
\text { cholecystectomy }\end{array}$ & $\begin{array}{l}\text { Bolus + } \\
\text { continuous } \\
\text { infusion }\end{array}$ & $\begin{array}{c}25 \\
\mathrm{mg} / \mathrm{kg} / \mathrm{h}\end{array}$ & I & $40 / 40$ & Saline & $16.1 \pm 8.6$ & $27.2 \pm 9.3$ \\
\hline $\begin{array}{c}\text { Kumar, } 2013 \\
{[20]}\end{array}$ & $\begin{array}{c}\text { Below umbilical } \\
\text { surgeries }\end{array}$ & $\begin{array}{l}\text { Bolus + } \\
\text { continuous } \\
\text { infusion }\end{array}$ & $\begin{array}{c}10 \\
\mathrm{mg} / \mathrm{kg} / \mathrm{h}\end{array}$ & I & $30 / 30$ & Saline & $3.99 \pm 1.25$ & $7.13 \pm 2.68$ \\
\hline
\end{tabular}

Abbreviations: Mg—Magnesium; mg—milligram; I—Intraoperative; P—Postoperative; mg—milligrams; h—hour; Kg—kilograms; min—minutes.

Subgroup analysis on the basis of time of intervention identified a significant reduction in the cumulative morphine consumption when Mg was administered either intraoperative (SMD: $-1.57,95 \%$ CI -2.20 to -0.93 ; $p<0.001$ ) or both intra and postoperative (SMD: $-1.32,95 \%$ CI -1.40 to $-0.80 ; p<0.001$ ) but no significant reduction with sole postoperative administration (SMD: $-0.30,95 \% \mathrm{CI}-1.11$ to $0.49 ; p=0.453$ ) (Figure 5).

However on further analysis between intra + postoperative dosing and only intraoperative dosing the decrease 


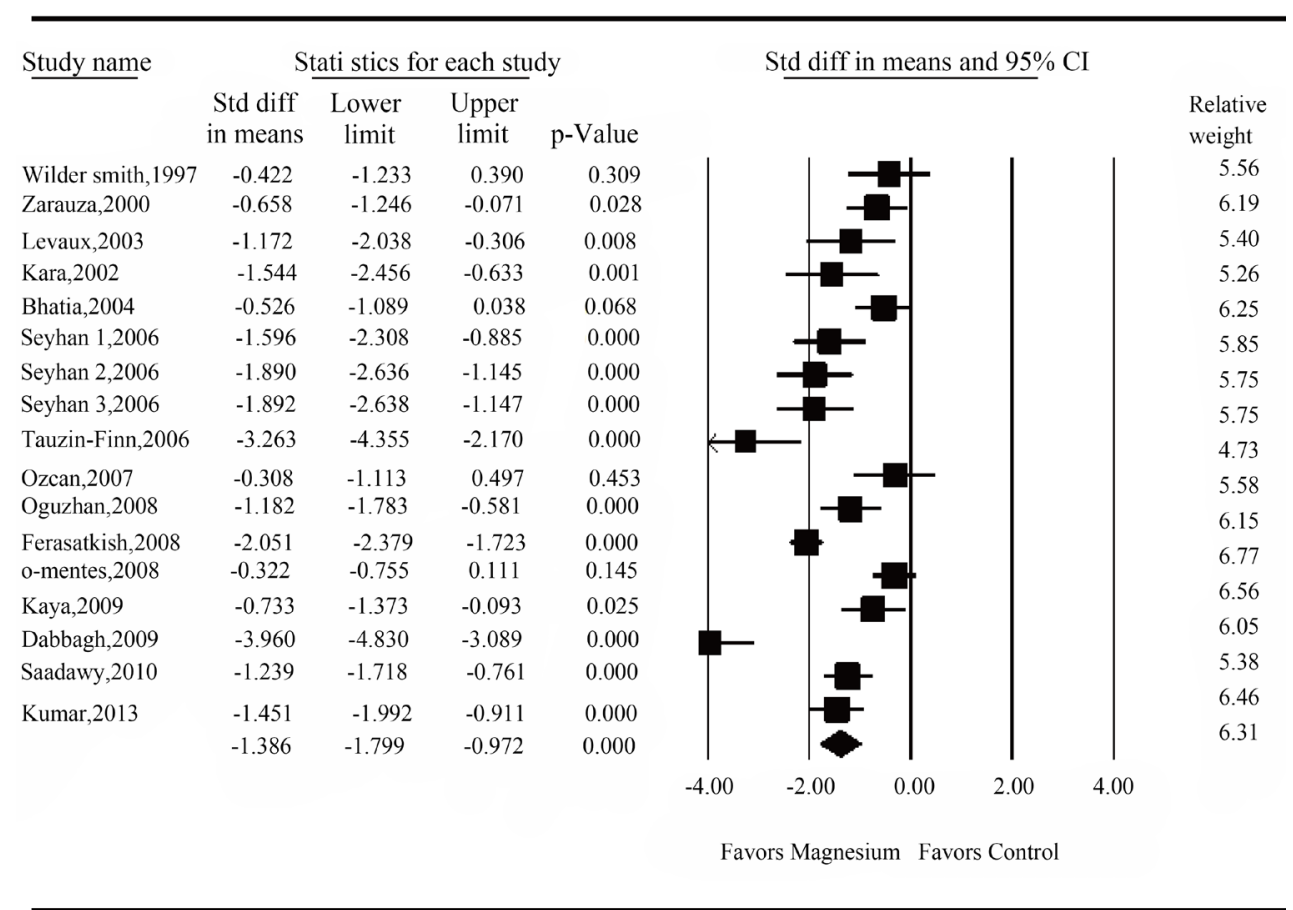

Figure 2. Forest plot evaluating the SMD (standard difference in means) in opioid consumption associated with administration of perioperative IV magnesium.

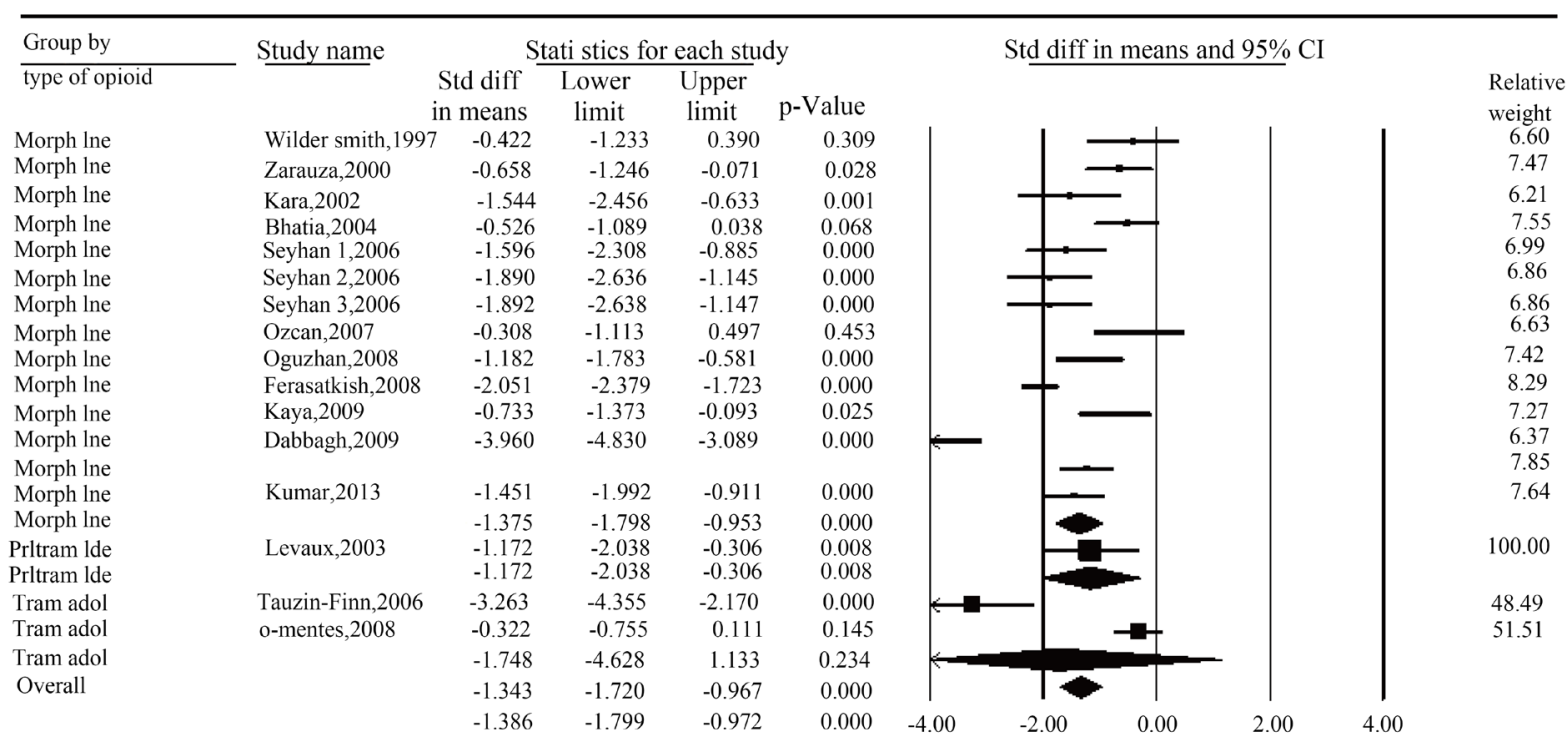

Favors Magnesium Favors Control

Figure 3. Forest plot evaluating the SMD (standard difference in means associated with administration of perioperative IV magnesium. (Subgroup analysis by type of opioid).

in opioid consumption seemed greater with both intraoperative and postoperative administration when compared to only intraoperative administration $(p<0.001)$.

A meta-regression analysis did not identify an association between the total magnesium dosage and an effect on postoperative opioid consumption (slope [95\% CI $=-0.00007[-0.00017$ to 0.00004$] p=0.21073$ compared with slope $=0$ ). 


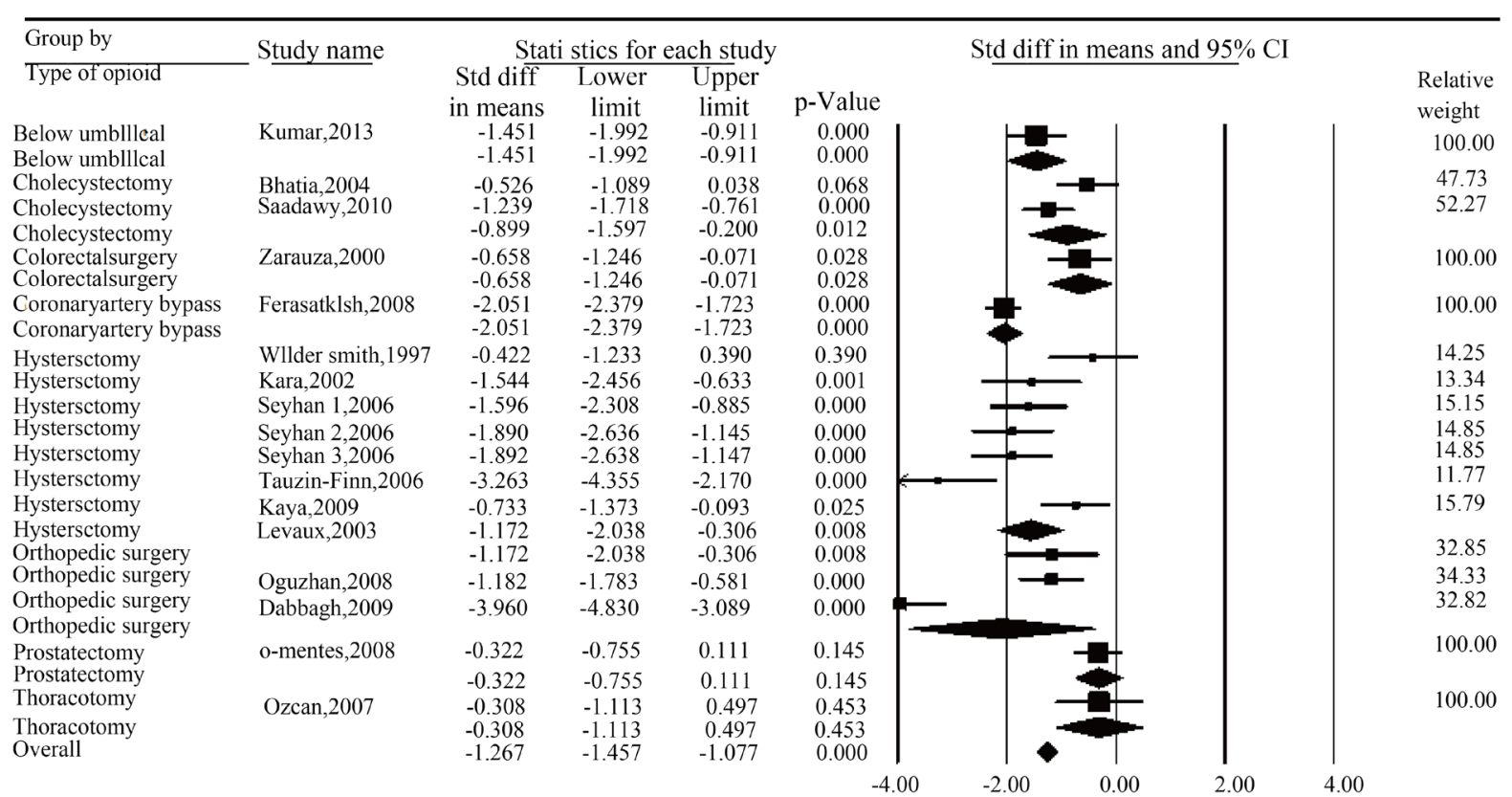

Favors Magnesium Favors Control

Figure 4. Forest plot evaluating the SMD (standard difference in means) in opioid consumption associated with administration of perioperative IV magnesium. (Subgroup analysis by type of surgery).

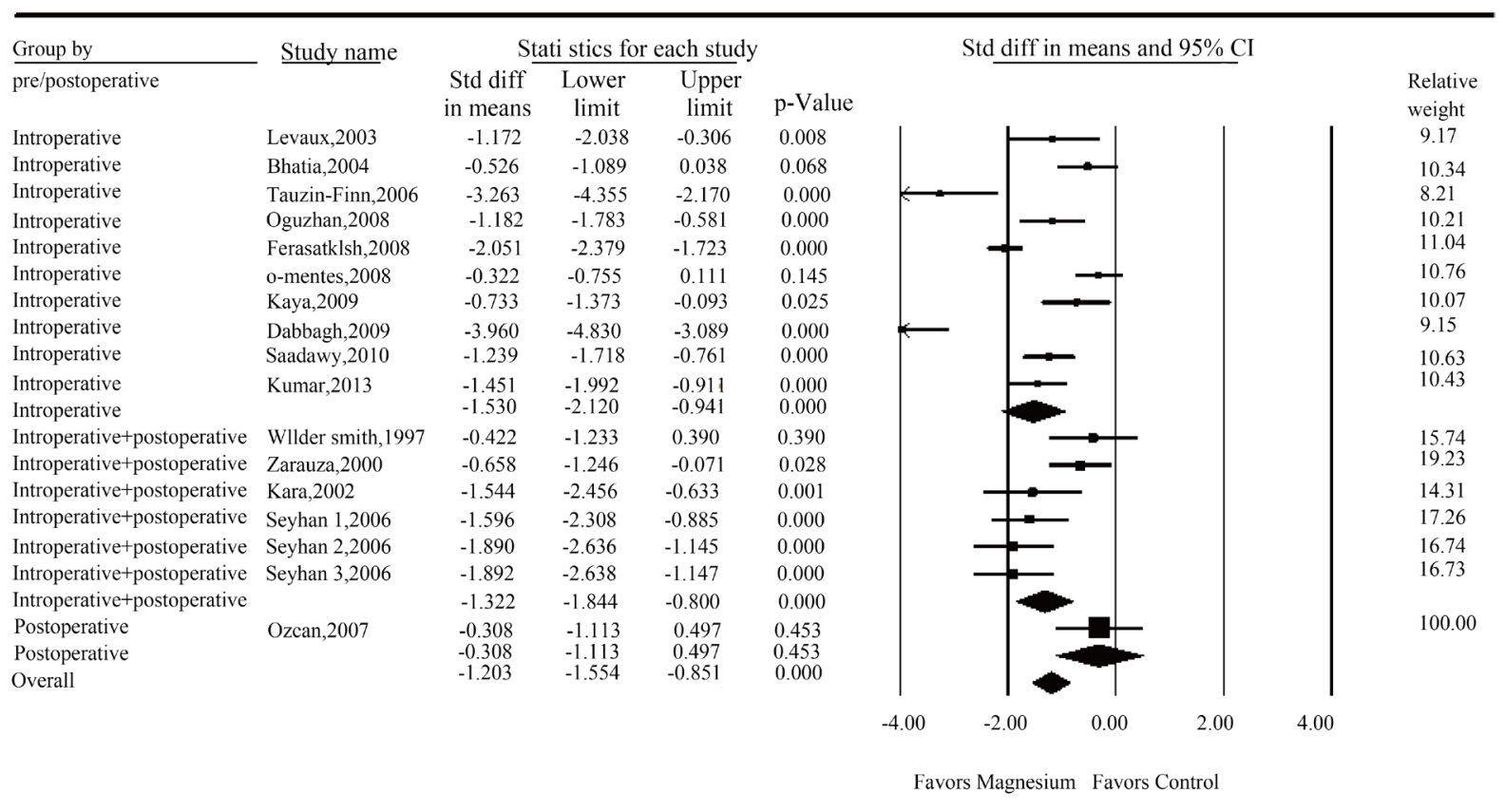

Figure 5. Forest plot evaluating the SMD (standard difference in means) in opioid consumption associated with administration of perioperative IV magnesium. (Subgroup analysis by time of administration).

\subsection{Effects of Magnesium on Nausea and Vomiting}

Data on the incidence of nausea and vomiting in both the Mg group and the placebo group was reported in 6 trials. There was no significant heterogeneity between trials $\left(p=0.988, \mathrm{I}^{2}=0.000\right)$, and a fixed-effects model was 
assumed. Although not statistically significant, the meta-analysis identified a trend towards decrease in the incidence of nausea and vomiting. ( $\mathrm{RR}=0.635$; $95 \% \mathrm{CI} 0.387$ to $1.044 ; p=0.074)$ (Figure 6). Individually, no trials reported significant differences in the incidence of nausea and vomiting.

\subsection{Publication Bias}

A funnel plot was used to visually assess for publication bias, and Egger's and Begg's tests were done to calculate publication bias. There was no obvious evidence of asymmetry on the funnel plot (Figure 7). Furthermore, there was no evidence of publication bias for the primary end point of this study (SMD in cumulative opioid consumption with use of Mg) by either the Egger's $(p=0.704)$ or Begg's test $(p=0.126)$.

\section{Discussion}

Effective postoperative pain control is an essential component of the care of surgical patients. The advantages of effective postoperative pain management include patient comfort and satisfaction, earlier mobilization, fewer pulmonary and cardiac complications, earlier return of bowel function, reduced risk of deep vein thrombosis, faster recovery with a lower likelihood of chronic or neuropathic pain, and reduced hospital costs [23]. Pain control has traditionally been achieved with opioid analgesia targeting central mechanisms involved in the

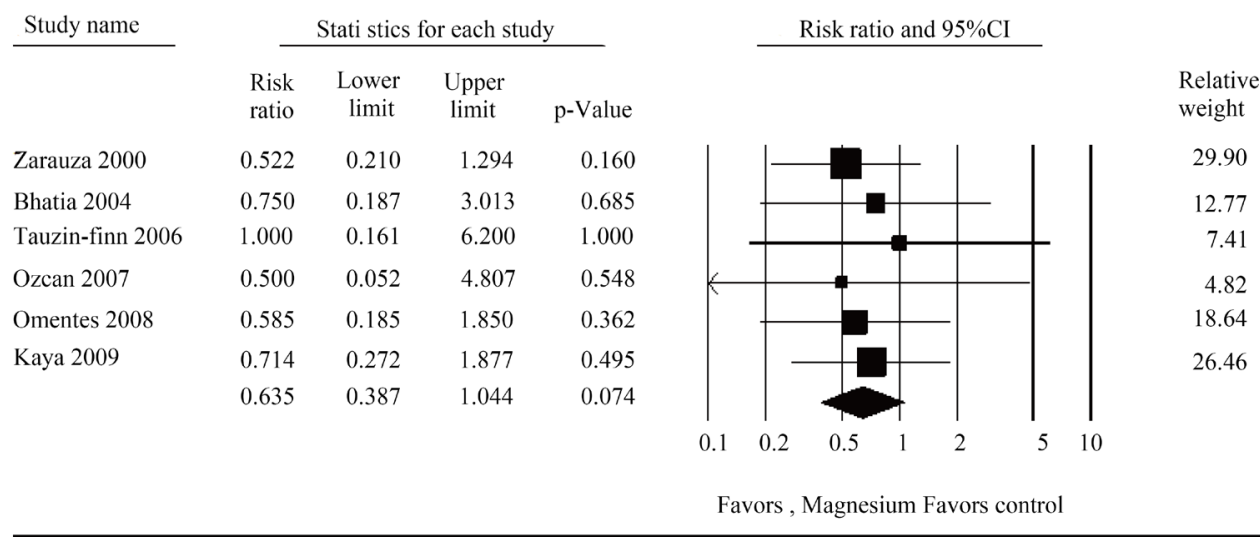

Figure 6. Forest plot evaluating the relative risk of incidence of nausea and vomiting associated with perioperative IV magnesium use.

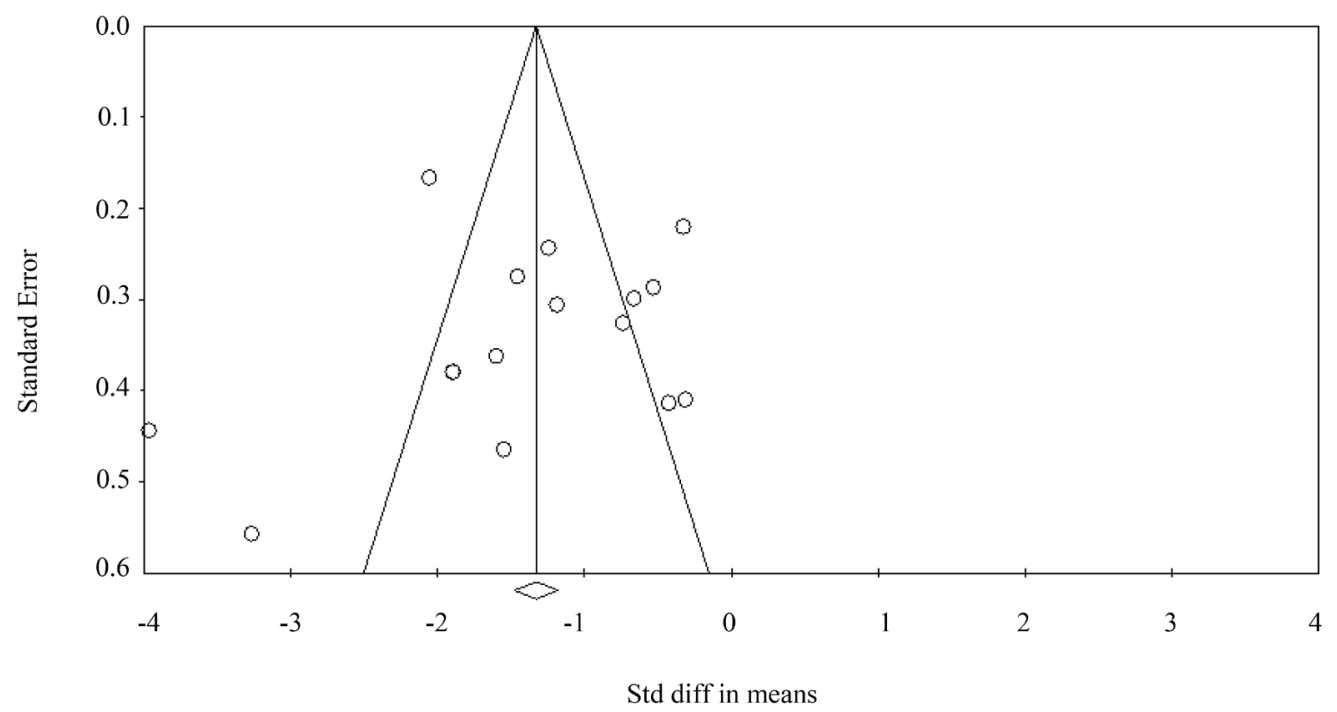

Figure 7. Funnel plot assessing publication bias (analyzing the effect of perioperative IV magnesium administration on opioid consumption. 
perception of pain. Drugs most commonly used include morphine, meperidine, fentanyl, and hydromorphone. While these agents are very effective analgesics, opioids also carry with them many undesirable side effects including sedation, respiratory depression, nausea and vomiting, hypotension and bradycardia, pruritus, and inhibition of bowel function [11].

Multimodal pain management implies choosing analgesic medications which work via different pharmacologic mechanisms of action and have additive or synergistic effects by acting at different sites within the central and/or peripheral nervous system [24]. The ultimate goal of the approach is to provide optimal pain control, while limit postoperative opioid requirements and therefore, decrease their associated adverse effects.

Magnesium sulfate has been used extensively for the prevention of pre-eclamptic seizures and as a tocolytic to prevent preterm labor [25] [26]. Magnesium sulfate is also effective in the management of tricyclic acid poisoning and drug induced Torsades de pointes [27] [28]. Mg has more recently been reported to exhibit numerous physiological activities including anti-nociceptive effects [29]. The mechanism of analgesia for Mg is unclear; however, several possible mechanisms have been proposed, including inhibition of calcium influx, antagonism of N-methyl-D-aspartate receptors, and attenuation of central sensitization [30] [31]. Wu et al. published a metaanalysis involving 729 patients and reported that compared with placebo, NMDA receptor antagonists (Mg and Ketamine) reduced the pain scores at $0,4,6,8,12$, and 24 hours postoperatively $(p<0.05)$ and reduced the cumulative analgesic consumption 6, 24, and 48 hours after surgery $(p<0.05)$.

The results of this meta-analysis demonstrate a significant reduction in opioid consumption $(\mathrm{MD}=-8.90 \mathrm{mg}$, $95 \%$ CI -11.18 to $-6.62 \mathrm{mg}$ morphine IV equivalents; $p<0.001$ ) with the administration of perioperative IV $\mathrm{Mg}$ which is consistent with a prior meta-analysis by Olivera et al. (2013) (WMD = $-10.52 \mathrm{mg}$; $95 \% \mathrm{CI}$, -13.5 .4 to $-7.54 \mathrm{mg}$ morphine IV equivalents, $p<0.001$ ) [32]. Although there was a significant reduction in postoperative cumulative morphine consumption in the first 24 hrs postoperatively, the reduction in tramadol consumption was not statistically significant. Another important finding of this meta-analysis was the detection of greater decrease in opioid consumption, when magnesium was administered both during the intraoperative and postoperative period as compared with the sole intraoperative administration of the drug.

There was a significant reduction in postoperative opioid consumption in coronary artery bypass surgeries, cholecystectomy, colorectal surgeries, abdominal hysterectomy and prostatectomy surgeries. A slight reduction in postoperative opioid consumption in thoracotomy, infra-umbilical and orthopedic surgeries were observed but failed to reach statistical significance. When Mg was administered either intraoperative or both intra and postoperatively the reduction in cumulative morphine consumption was statistically significant. However postoperative administration of $\mathrm{Mg}$ alone did not demonstrate a significant reduction in morphine consumption. The incidence of nausea and vomiting, common side effects of opioids remained similar even with the reduction in cumulative opioid consumption.

There are several limitations to this study. Not all studies used the same opioid for postoperative analgesia. Although most studies used morphine, 2 studies used tramadol, which were converted to equi-analgesic doses of morphine for analysis. In addition, there was limited available data on opioid-related side effects other than postoperative nausea and vomiting. Moreover, there was either limited data or no reported data on pruritus, sedation, urinary retention, and respiratory depression. Nevertheless, it is unlikely that perioperative magnesium infusion would have a significant effect on major adverse events such as respiratory depression; as prior studies indicate that perioperative administration of other adjuvants (e.g. Acetaminophen, non-steroidal anti-inflammatory agents, and ketamine) do not significantly decrease opioid related adverse events despite the presence of an opioid-sparing effect [33] [34]. Additional studies are required to optimize the magnesium dose and timing, and to address whether specific opioids display unique benefit or resistance to adjuvant magnesium therapy. The sample size of the included studies was relatively small ( $<50$ subjects/study) and as a result, there may have been little data on less frequent outcomes of interest (such as respiratory depression).

\section{Conclusion}

In conclusion, perioperative adjunct IV Mg administration reduces opioid consumption in the first 24 hours postoperatively, without serious adverse events. The decrease in opioid consumption is more beneficial in gynecological, cholecystectomy, colorectal, and coronary bypass surgeries. $\mathrm{Mg}$ is an efficacious adjunct for postoperative analgesia and should be considered in multimodal analgesic treatment plans. 


\section{Acknowledgements}

The authors would like to acknowledge Sungyub Lew, Research Fellow, Saint Barnabas Medical Center-Surgical Outcomes and Analytics Research Institute, for his statistical assistance which supported this manuscript.

\section{References}

[1] Tsui, S.L., Law, S., Fok, M., Lo, J.R., Ho, E., Yang, J., et al. (1997) Postoperative Analgesia Reduces Mortality and Morbidity after Esophagectomy. American Journal of Surgery, 173, 472-478. http://dx.doi.org/10.1016/S0002-9610(97)00014-7

[2] Seeling, W. and Rockemann, M. (1993) Influence of Postoperative Pain on Morbidity and Mortality. Schmerz, 7, 85-96. http://dx.doi.org/10.1007/BF02527865

[3] Lovich-Sapola, J., Smith, C.E. and Brandt, C.P. (2015) Postoperative Pain Control. Surgical Clinics of North America, 95, 301-318. http://dx.doi.org/10.1016/j.suc.2014.10.002

[4] Khan, R.S., Ahmed, K., Blakeway, E., Skapinakis, P., Nihoyannopoulos, L., Macleod, K., et al. (2011) Catastrophizing: A Predictive Factor for Postoperative Pain. American Journal of Surgery, 201, 122-131. http://dx.doi.org/10.1016/j.amjsurg.2010.02.007

[5] Macrae, W.A. (2008) Chronic Post-Surgical Pain: 10 Years on. British Journal of Anaesthesia, 101, 77-86. http://dx.doi.org/10.1093/bja/aen099

[6] Searle, R.D., Simpson, M.P., Simpson, K.H., Milton, R. and Bennett, M.I. (2009) Can Chronic Neuropathic Pain Following Thoracic Surgery Be Predicted during the Postoperative Period? Interactive Cardiovascular and Thoracic Surgery, 9, 999-1002. http://dx.doi.org/10.1510/icvts.2009.216887

[7] Clarke, H., Poon, M., Weinrib, A., Katznelson, R., Wentlandt, K. and Katz, J. (2015) Preventive Analgesia and Novel Strategies for the Prevention of Chronic Post-Surgical Pain. Drugs, 75, 339-351. http://dx.doi.org/10.1007/s40265-015-0365-2

[8] Perkins, F.M. and Kehlet, H. (2000) Chronic Pain as an Outcome of Surgery. A Review of Predictive Factors. Anesthesiology, 93, 1123-1133. http://dx.doi.org/10.1097/00000542-200010000-00038

[9] Ashburn, M.A., Love, G. and Pace, N.L. (1994) Respiratory-Related Critical Events with Intravenous Patient-Controlled Analgesia. Clinical Journal of Pain, 10, 52-56. http://dx.doi.org/10.1097/00002508-199403000-00007

[10] Etches, R.C. (1994) Respiratory Depression Associated with Patient-Controlled Analgesia: A Review of Eight Cases. Canadian Journal of Anesthesia, 41, 125-132. http://dx.doi.org/10.1007/BF03009805

[11] Oderda, G.M., Said, Q., Evans, R.S., Stoddard, G.J., Lloyd, J., Jackson, K., et al. (2007) Opioid-Related Adverse Drug Events in Surgical Hospitalizations: Impact on Costs and Length of Stay. Annals of Pharmacotherapy, 41, 400-406. http://dx.doi.org/10.1345/aph.1H386

[12] Joshi, S.S. and Jagadeesh, A.M. (2013) Efficacy of Perioperative Pregabalin in Acute and Chronic Post-Operative Pain after Off-Pump Coronary Artery Bypass Surgery: A Randomized, Double-Blind Placebo Controlled Trial. Annals of Cardiac Anaesthesia, 16, 180-185. http://dx.doi.org/10.4103/0971-9784.114239

[13] White, P.F. (2008) Multimodal Analgesia: Its Role in Preventing Postoperative Pain. Current Opinion in Investigational Drugs, 9, 76-82.

[14] Costantini, R., Affaitati, G., Fabrizio, A. and Giamberardino, M.A. (2011) Controlling Pain in the Post-Operative Setting. International Journal of Clinical Pharmacology and Therapeutics, 49, 116-127. http://dx.doi.org/10.5414/CP201401

[15] Lyell, D.J., Pullen, K., Campbell, L., Ching, S., Druzin, M.L., Chitkara, U., et al. (2007) Magnesium Sulfate Compared with Nifedipine for Acute Tocolysis of Preterm Labor: A Randomized Controlled Trial. Obstetrics \& Gynecology, 110, 61-67. http://dx.doi.org/10.1097/01.AOG.0000269048.06634.35

[16] Berhan, Y. and Berhan, A. (2015) Should Magnesium Sulfate Be Administered to Women with Mild Pre-Eclampsia? A Systematic Review of Published Reports on Eclampsia. Journal of Obstetrics and Gynaecology Research, 41, 831842. http://dx.doi.org/10.1111/jog.12697

[17] McCarthy, R.J., Kroin, J.S., Tuman, K.J., Penn, R.D. and Ivankovich, A.D. (1998) Antinociceptive Potentiation and Attenuation of Tolerance by Intrathecal Co-Infusion of Magnesium Sulfate and Morphine in Rats. Anesthesia \& Analgesia, 86, 830-836.

[18] Dube, L. and Granry, J.C. (2003) The Therapeutic Use of Magnesium in Anesthesiology, Intensive Care and Emergency Medicine: A Review. Canadian Journal of Anaesthesia, 50, 732-746. http://dx.doi.org/10.1007/BF03018719

[19] Murphy, J.D., Paskaradevan, J., Eisler, L.L., Ouanes, J.P., Tomas, V.A., Freck, E.A., et al. (2013) Analgesic Efficacy of Continuous Intravenous Magnesium infusion as an Adjuvant to Morphine for Postoperative Analgesia: A Systematic 
Review and Meta-Analysis. Middle East Journal of Anaesthesiology, 22, 11-20.

[20] Kumar, M., Dayal, N., Rautela, R.S. and Sethi, A.K. (2013) Effect of Intravenous Magnesium Sulphate on Postoperative Pain Following Spinal Anesthesia. A Randomized Double Blind Controlled Study. Middle East Journal of Anaesthesiology, 22, 251-256.

[21] Frassanito, L., Messina, A., Vergari, A., Colombo, D., Chierichini, A., Della, C.F., et al. (2015) Intravenous Infusion of Magnesium Sulfate and Postoperative Analgesia in Total Knee Arthroplasty. Minerva Anestesiologica, 81, 11841191.

[22] Cohen, J. (1988) Statistical Power Analysis for the Behavioral Sciences. 2nd Edition, Routledge, Hillsdale.

[23] Lovich-Sapola, J., Smith, C.E. and Brandt, C.P. (2015) Postoperative Pain Control. Surgical Clinics of North America, 95, 301-318. http://dx.doi.org/10.1016/j.suc.2014.10.002

[24] Elvir-Lazo, O.L. and White, P.F. (2010) The Role of Multimodal Analgesia in Pain Management after Ambulatory Surgery. Current Opinion in Anaesthesiology, 23, 697-703. http://dx.doi.org/10.1097/ACO.0b013e32833fad0a

[25] Simon, J., Gray, A. and Duley, L. (2006) Cost-Effectiveness of Prophylactic Magnesium Sulphate for 9996 Women with Pre-Eclampsia from 33 Countries: Economic Evaluation of the Magpie Trial. BJOG, 113, 144-151. http://dx.doi.org/10.1111/j.1471-0528.2005.00785.x

[26] Hunter, L.A. and Gibbins, K.J. (2011) Magnesium Sulfate: Past, Present, and Future. Journal of Midwifery \& Women's Health, 56, 566-574. http://dx.doi.org/10.1111/j.1542-2011.2011.00121.x

[27] Altman, D., Carroli, G., Duley, L., Farrell, B., Moodley, J., Neilson, J., et al. (2002) Do Women with Pre-Eclampsia, and Their Babies, Benefit from Magnesium Sulphate? The Magpie Trial: A Randomised Placebo-Controlled Trial. The Lancet, 359, 1877-1890. http://dx.doi.org/10.1016/S0140-6736(02)08778-0

[28] Witlin, A.G. and Sibai, B.M. (1998) Magnesium Sulfate Therapy in Preeclampsia and Eclampsia. Obstetrics \& Gynecology, 92, 883-889. http://dx.doi.org/10.1097/00006250-199811000-00028

[29] Vuckovic, S., Srebro, D., Savic, V.K. and Prostran, M. (2015) The Antinociceptive Effects of Magnesium Sulfate and MK-801 in Visceral Inflammatory Pain Model: The Role of NO/cGMP/K ATP Pathway. Pharmaceutical Biology, 53, 1621-1627. http://dx.doi.org/10.3109/13880209.2014.996821

[30] Iseri, L.T. and French, J.H. (1984) Magnesium: Nature’s Physiologic Calcium Blocker. American Heart Journal, 108, 188-193. http://dx.doi.org/10.1016/0002-8703(84)90572-6

[31] Woolf, C.J. and Thompson, S.W. (1991) The Induction and Maintenance of Central Sensitization Is Dependent on N-Methyl-D-Aspartic Acid Receptor Activation, Implications for the Treatment of Post-Injury Pain Hypersensitivity States. Pain, 44, 293-299. http://dx.doi.org/10.1016/0304-3959(91)90100-C

[32] De Oliveira, G.S.J., Castro-Alves, L.J., Khan, J.H. and McCarthy, R.J. (2013) Perioperative Systemic Magnesium to Minimize Postoperative Pain: A Meta-Analysis of Randomized Controlled Trials. Anesthesiology, 119, 178-190. http://dx.doi.org/10.1097/ALN.0b013e318297630d

[33] Remy, C., Marret, E. and Bonnet, F. (2005) Effects of Acetaminophen on Morphine Side-Effects and Consumption after Major Surgery: Meta-Analysis of Randomized Controlled Trials. British Journal of Anaesthesia, 94, 505-513. http://dx.doi.org/10.1093/bja/aei085

[34] Bell, R.F., Dahl, J.B., Moore, R.A. and Kalso, E. (2006) Perioperative Ketamine for Acute Postoperative Pain. Cochrane Database of Systematic Reviews, 25, Article No. CD004603. http://dx.doi.org/10.1002/14651858.cd004603.pub2

[35] Wilder-Smith, C.H., Knopfli, R. and Wilder-Smith, O.H.G. (1997) Perioperative Magnesium Infusion and Postoperative Pain. Acta Anaesthesiologica Scandinavica, 41, 1023-1027. http://dx.doi.org/10.1111/j.1399-6576.1997.tb04830.x

[36] Zarauza, R., Saez-Fernandez, A.N., Iribarren, M.J., Carrascosa, F., Adame, M., Fidalgo, I., et al. (2000) A Comparative Study with Oral Nifedipine, Intravenous Nimodipine, and Magnesium Sulfate in Postoperative Analgesia. Anesthesia \& Analgesia, 91, 938-943. http://dx.doi.org/10.1097/00000539-200010000-00032

[37] Kara, H., Sahin, N., Ulusan, V. and Aydogdu, T. (2002) Magnesium Infusion Reduces Perioperative Pain. European Journal of Anaesthesiology, 19, 52-56. http://dx.doi.org/10.1017/S026502150200008X

[38] Levaux, C., Bonhomme, V., Dewandre, P.Y., Brichant, J.F. and Hans, P. (2003) Effect of Intra-Operative Magnesium Sulphate on Pain Relief and Patient Comfort after Major Lumbar Orthopaedic Surgery. Anaesthesia, 58, 131-135. http://dx.doi.org/10.1046/j.1365-2044.2003.02999.x

[39] Bhatia, A., Kashyap, L., Pawar, D.K. and Trikha, A. (2004) Effect of Intraoperative Magnesium Infusion on Perioperative Analgesia in Open Cholecystectomy. Journal of Clinical Anesthesia, 16, 262-265. http://dx.doi.org/10.1016/j.jclinane.2003.08.012

[40] Seyhan, T.O., Tugrul, M., Sungur, M.O., Kayacan, S., Telci, L., Pembeci, K., et al. (2006) Effects of Three Different Dose Regimens of Magnesium on Propofol Requirements, Haemodynamic Variables and Postoperative Pain Relief in Gynaecological Surgery. British Journal of Anaesthesia, 96, 247-252. http://dx.doi.org/10.1093/bja/aei291 
[41] Tauzin-Fin, P., Sesay, M., Delort-Laval, S., Krol-Houdek, M.C. and Maurette, P. (2006) Intravenous Magnesium Sulphate Decreases Postoperative Tramadol Requirement after Radical Prostatectomy. European Journal of Anaesthesiology, 23, 1055-1059. http://dx.doi.org/10.1017/S0265021506001062

[42] Ozcan, P.E., Tugrul, S., Senturk, N.M., Uludag, E., Cakar, N., Telci, L., et al. (2007) Role of Magnesium Sulfate in Postoperative Pain Management for Patients Undergoing Thoracotomy. Journal of Cardiothoracic and Vascular Anesthesia, 21, 827-831. http://dx.doi.org/10.1053/j.jvca.2006.11.013

[43] Mentes, O., Harlak, A., Yigit, T., Balkan, A., Balkan, M., Cosar, A., et al. (2008) Effect of Intraoperative Magnesium Sulphate Infusion on Pain Relief after Laparoscopic Cholecystectomy. Acta Anaesthesiologica Scandinavica, 52, 13531359. http://dx.doi.org/10.1111/j.1399-6576.2008.01816.x

[44] Ferasatkish, R., Dabbagh, A., Alavi, M., Mollasadeghi, G., Hydarpur, E., Moghadam, A.A., et al. (2008) Effect of Magnesium Sulfate on Extubation Time and Acute Pain in Coronary Artery Bypass Surgery. Acta Anaesthesiologica Scandinavica, 52, 1348-1352. http://dx.doi.org/10.1111/j.1399-6576.2008.01783.x

[45] Oguzhan, N., Gunday, I. and Turan, A. (2008) Effect of Magnesium Sulfate Infusion on Sevoflurane Consumption, Hemodynamics, and Perioperative Opioid Consumption in Lumbar Disc Surgery. Journal of Opioid Management, 4, 105-110.

[46] Kaya, S., Kararmaz, A., Gedik, R. and Turhanoglu, S. (2009) Magnesium Sulfate Reduces Postoperative Morphine Requirement after Remifentanil-Based Anesthesia. Medical Science Monitor, 15, I5-I9.

[47] Dabbagh, A., Elyasi, H., Razavi, S.S., Fathi, M. and Rajaei, S. (2009) Intravenous Magnesium Sulfate for Post-Operative Pain in Patients Undergoing Lower Limb Orthopedic Surgery. Acta Anaesthesiologica Scandinavica, 53, 10881091. http://dx.doi.org/10.1111/j.1399-6576.2009.02025.x

[48] Saadawy, I.M., Kaki, A.M., Abd El-Latif, A.A., Abd-Elmaksoud, A.M. and Tolba, O.M. (2010) Lidocaine vs. Magnesium: Effect on Analgesia after a Laparoscopic Cholecystectomy. Acta Anaesthesiologica Scandinavica, 54, 549-556. http://dx.doi.org/10.1111/j.1399-6576.2009.02165.x 